\title{
AKKULTURAATIO BOSNIAN MUSLIMIEN MUSIIKKIKULTTUURISSA
}

Bosnia-Hertsegovina on Euroopan pohjoisin yhtenäinen muslimialue. Bosnian kuuluminen neljän vuosisadan (1463-1878) ajan osmanien valtakuntaan vaikutti maakunnan kulttuuriin kahdella tapaa. Yhtäältä turkkilaiset toivat mukanaan uskontonsa, elämäntyylinsä sekä urbaanit kulttuuri-instituutionsa ja toisaalta heidän valtakautensa eristi Balkanin Keski-Euroopan kulttuurikehityksestä.

Bosniassa turkkilainen vaikutus rajoittuu pääasiassa kaupunkeihin. Niinpä Bosnian muslimien musiikki jakaantuu kahteen täysin erilaiseen traditioon: arkaaiseen maaseutu- ja orientaaliseen kaupunkiperinteeseen. Kahtiajako johtuu osmanien hallintomallista Balkanilla. Sotilaspartioita lukuun ottamatta turkkilaiset välttelivät maaseutua, joten he olivat läsnä vain tärkeillä kulkuväylillä ja kaupungeissa. Veronkanto annettiin kirkon tehtäväksi. Hallintomalli antoi maalaisväestölle varsin huomattavan uskonnollisen ja kulttuurisen vapauden. (Dietrich 1983, 7).

Osmanien valtakunnan ja Itävallan välinen pitkään jatkunut sotatila katkaisi lähes kaikki Keski-Euroopan ja Balkanin kulttuuriyhteydet. Tämän vuoksi Balkanin maaseudulla on säilynyt vielä tähän päivään saakka arkaaisia erityistekniikoita suosivia paikallisia musiikkikulttuureja, kun länsimaistyylinen moniäänisyys on puolestaan uudehko ilmiö. 
(ibid.).

Bosnian kaupunkimusiikkiin kotiutuneet itämaisperäiset piirteet ovat kiinnostaneet musiikintutkijoita, ja asiasta on kirjoitettu paljon (ks. esim. Kuhać 1898; Rihtman 1966; Petrović 1989). Sen sijaan KeskiEuroopasta 1880-luvulta lähtien saapuneet innovaatiot ovat jääneet vähälle huomiolle. Tutkijat eivät ole kiinnittäneet huomiota läntisiin vaikutteisiin ehkä sen vuoksi, että he ovat olleet kiinnostuneita uuden sijasta vanhasta ja katoavasta. Bosnian muslimit itse ovat taas tottuneet korostamaan kulttuurinsa itämaispohjaisuutta vahvistaakseen etnistä identiteettiään ja erottuakseen maakunnan kristityistä serbeistä ja kroaateista.

Muslimien kansallistunne alkoi kehittyä 1800-luvulla. Sen pohjana olivat yhteinen uskonto ja kulttuuri sekä historialliset, sosiaaliset ja taloudelliset syyt. Bosnian muslimit eivät kyenneet samastumaan ortodokseihin, katolisiin tai turkkilaisiin. Kansallistunne ilmeni selvästi BosniaHertsegovinan lukuisten kapinoiden yhteydessä, jolloin muslimit toimivat itsenäisenä, turkkilaisista vallanpitäjistä riippumattomana poliittisena ja kulttuurisena kokonaisuutena. (Filipović \& Hadžidedić 1983, 126).

Kesti pitkään ennen kuin muslimit määriteltiin virallisesti kansallisuudeksi. Sosialistisen Jugoslavian vuosien 1953 ja 1961 väestönlaskennoissa Bosnia-Hertsegovinan muslimeja pidettiin selvittämättömänä kansallisuutena tai etnisenä ryhmänä. Bosnia-Hertsegovinan sosialistisen tasavallan 1963 uusittu perustuslaki virallisti muslimikansallisuuden, joten vuoden 1971 väestönlaskennassa muslimit otettiin huomioon omana ryhmänään. Muslimien aseman muutos liittyy Jugoslavian kansallisuuspolitiikan kehitykseen. Ajatus Jugoslaviasta kansojen yhteisönä syrjäytti aiemmin vallinneen jugoslavialaisuuden 1960-luvulla. (Ibid., 127; Lockwood 1975, 27).

Seuraavassa tarkastelen bosnialaisen musiikkikulttuurin piirteitä maakuntaan akkulturoituneiden musiikki-ilmiöiden ja kahden sävelmän avulla. Analysoin materiaalia sekä bosnialaisesta että turkkilaisesta näkökulmasta.

\section{Turkkilaisen makam-järjestelmän muuntuminen Bosniassa}

Signell $(1977,16)$ määrittelee turkkilaisen makamin sävellyssäännöstöksi, jonka avulla luodaan musiikkikappaleen melodinen aines. Nykyisin 
Turkissa käytetään noin 70 makamia, joilla kullakin on oma nimensä ja intervallirakenteensa. Teoria tuntee viisi perusintervallia, jotka ilmaistaan pythagoralaisen komman avulla. Ne ovat heikko puoliaskel (4 kommaa), puoliaskel (5 kommaa), heikko kokoaskel (8 kommaa), kokoaskel (9 kommaa) sekä vahva kokoaskel (12 kommaa). (Ibid. 22-23).

Kutakin makamia noudattavan melodian etenemistä määrää seyirsäännöstö. Seyir sanelee melodian pysähdyspaikat eli makamin akselisävelet. Niistä toonika eli finalis (karar) päättää melodian. Ylätoonikalla (tiz durak) on usein tärkeä asema seyirissä. Sisääntulo (giriş) on sävel, jonka ympärillä melodian ensimmäinen säe liikkuu, ja se voi olla toonika, dominantti tai ylätoonika. Dominantti (güçlü) on tärkeä akselisävel sisääntulon ja finaliksen puolivälissä. Se on usein kvintin tai kvartin päässä toonikasta, mutta välimatka voi olla myös terssi. Väliaikaiset pysähdykset (muvakkat kalışlar) eivät tunnu yhtä lopullisilta kuin toonika eivätkä yhtä hallitsevilta kuin dominantti. Ilman niitä kunkin makamin seyir menettäisi yksilöllisyytensä. Melodian pysähtyminen akselisävelille merkitsee lepotilaa. Funktioltaan sävelet ovat verrattain passiivisia, joskin toonika on kaikkein epäaktiivisin. (Ibid. 48-49).

Funktioltaan erittäin aktiiviset sävelet akselisävelten välissä auttavat osaltaan määrittämään melodialinjan etenemistä. Niistä tärkeimmät ovat johtosävel (yeden) ja pidätetty kadenssi (asma karar). Johtosävel sijaitsee makamista riippuen koko- tai puolisävelaskeleen toonikan alapuolella. Pidätetty kadenssi syntyy, kun melodia pysähtyy jollekin akselisäveliin kuulumattomalle aktiiviselle sävelelle. Pysähtyminen synnyttää voimakkaan levottomuuden ja vaillinaisuuden tunteen. Melodialinjan kromaattiset merkit eivät siis välttämättä tarkoita modulaatiota, koska makamien perusasteikoissa on sekä kiinteitä että muuntuvia säveliä. (Ibid. 49).

Kunkin makamin seyirillä on melodinen suunta, joka voi olla nouseva, laskeva tai niiden välimuoto. Suunta määräytyy sisääntulosävelen ja finaliksen keskinäisestä suhteesta. Nousevaa seyiriä noudattava melodialinja alkaa toonikan lähistöltä, nousee vähitellen dominanttiin ja palaa lopulta toonikaan. (Ibid. 50).

Makam segâhin (ks. esim. 1) toonika- eli finalissävel on segâh. ${ }^{1}$ Sa-

1 Turkkilaisista sävelnimistä ks. Signell 1977, 26-29. 
malla se on sisääntulosävel. Dominantti on kolmas aste. Väliaikainen pysähdys sattuu usein fis-sävelen (eviç) kohdalle. Alaspäisissä melodiakuluissa fis saattaa tasaantua f-säveleksi (acem). Vastaava ilmiö tapahtuu useissa muissakin makameissa (ks. ibid., 43). Johtosävel on ais (kürdi). Makamin seyir on nouseva.

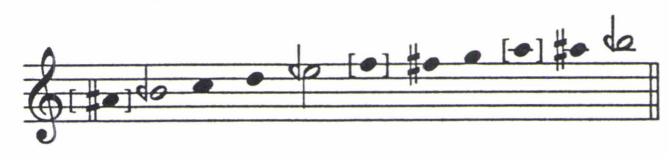

Esimerkki 1. Makam segâh.

\section{Bosnialainen mekam}

Bosnialaiset tutkijat määrittelevät mekamin Bosnia-Hertsegovinan muslimien sakraaliksi laulannaksi. ${ }^{2}$ Heidän mukaansa ezan-rukouskutsussa, koraaniresitaatiossa, resitoiduissa rukouksissa sekä mystikkoveljeskuntien rituaalilaulannassa sulautuu yhteen bosnialaisia ja arabialais-turkkilaisia piirteitä. (Ks. Hadžisalihović 1973, 248; Petrović 1989, 131; Spaić 1989, 46).

Hadžisalihović $(1973,249)$ luettelee mekamin ominaisuuksia. Sen ambitus on pienempi ja koristeiden käyttö vähäisempää kuin arabialaisessa maqāmissa ja turkkilaisessa makamissa. Mekamin peräkkäiset puolisävelaskeleet ja intervallien häilyvyys ovat tyypillisiä myös BosniaHertsegovinan maaseudun vokaalimusiikille. Melodia seuraa sanojen rytmiä.

Petrović $(1982,41)$ arvelee, että on olemassa useita käsitteellisesti ja rakenteellisesti löyhästi määriteltyjä mekameja. Niitä voidaan käyttää saman musiikillisen kokonaisuuden sisällä, ja ne saatetaan tulkita myös yhdeksi mekamiksi. Toisin kuin useimmat bosnialaiset tutkijat Petrović ajattelee mekamin olevan ainakin jossain määrin makamin kaltainen sä-

$\begin{array}{ll}\text { Nostaa } 1 \text { komman } & \text { Laskee } 1 \text { komman d } \\ \text { Nostaa } 4 \text { kommaa } & \text { Laskee } 4 \text { kommaa } \frac{1}{6} \\ \text { Nostaa } 5 \text { kommaa } \frac{\phi}{\phi} & \text { Laskee } 5 \text { kommaa b }\end{array}$

2 Mekamin muita nimityksiä ovat bosanski mekam 'bosnialainen mekam' ja sarajevski mekam 'sarajevolainen mekam'. 
vellyssäännöstö.

Mekamin ominaisuudet vaihtelevat Bosnia-Hertsegovinan eri alueilla. Sarajevossa ja muissa taajamissa ambitus on kvinttiä suurempi, kun taas maaseudulla sitä pienempi. Kaupungeissa mekamia esitetään maaseutua melismaattisemmin. Tyypillinen intervalli on ylinouseva sekunti, jonka molemmin puolin on puolisävelaskel. (Ibid.).

Jugoslavialaiset tutkijat eivät kykene määrittelemään selkeästi käsitteitä 'makam' ja 'mekam'. Ainakin osa heistä olettaa turkkilaisen makamin olevan bosnialaisen mekamin tavoin uskonnollista laulantaa. He eivät yleensä kirjoita mekameja asteikkomuotoon, vaan nuotintavat kokonaisia esityksiä. Vlado Milošević $(1983,63 ; 68)$ on harvoja poikkeuksia. Hän tulkitsee nuotintamiensa resitaatioiden seuraavan eri kirkkomoodeja. Maallikoiden käsitykset mekamista ovat yhtä lailla epämääräisiä kuin tutkijoidenkin (ks. Pennanen 1990, 163-164).

Loppujen lopuksi makam-ilmiö on bosnialaisille perin tuntematon. Tämä ilmenee uskonnollisten ilahija-hymnien ${ }^{3}$ muistiinmerkitsemisessä. Turkissa nämä hymnit otsikoidaan taidemusiikin käytännön mukaisesti kulloinkin käytetyn makamin mukaan. Myös usul-rytmimoodi mainitaan. Sen sijaan Bosniassa muistiin merkitään vain lauluteksti, jonka otsikoksi valitaan ensimmäisen säkeen tai kertosäkeen alku. Sarajevon dervissit eivät tunne usulin käsitettä, vaan puhuvat rytmista, ritam.

\section{Turkkilaisen hymnin bosnialaistuminen}

Tutkijat ja maallikot pitävät Bosnia-Hertsegovinassa tunnettuja ilahijahymnejä suurelta osin turkkilaisperäisinä. Turkkilaisten ilâhien ja niiden bosnialaistuneiden, Sarajevon dervissien tuntemien versioiden vertailu selventää Bosnian musiikkikulttuurista asemaa idän ja lännen välissä.

Ilâhi-teksteillä on aina ollut taipumus muuntua muistinvaraisuuden ja jatkuvan säkeiden lisäämisen vuoksi. ${ }^{4}$ Uusia tekstejä on syntynyt eri runoilijoiden teosten sulautuessa yhteen. Monien tekstien kirjoittajat ovat unohtuneet heidän nimensä sisältävän şahbeyt-säkeen kadottua. Osa ilâhi-runoista ja -lauluista on muuttunut kansanperinteeksi. Sama teksti on voinut saada useita erilaisia sävelasuja. (Boratav 1971, 1094).

\footnotetext{
3 Sanan turkinkielinen muoto on ilâhi.

4 Arabialaisen kirjallisuuden perinteeseen kuuluu runojen muokkaaminen esimerkiksi lisäämällä uusi säepari alkuperäiseen säepariin (ks. Schimmel 1982, 275, alaviite 7).
} 
Bosnia-Hertsegovinan muslimit ovat esittäneet serbokroaatinkielisten ohella myös arabian- tai turkinkielisiä ilahijoita, joista muutamat ovat päätyneet profaaneiksi sävelmiksi. Koska turkin ja arabian taito on vähäistä, näillä kielillä kirjoitettujen runojen bosnialaisversiot ovat voineet rapautua lähes tunnistamattomiksi. Myös melodiat ovat usein enemmän tai vähemmän muuntuneet. Liian mutkikkaaksi koettu turkkilainen sävelmä on saatettu korvata yksinkertaisemmalla.

Turkkilaisen Nezih Uzelin (1990) mukaan Server-i serbülendimiz on Sarı Abdullahin 1800-luvun lopulla kirjoittama turkinkielinen ilâhi. ${ }^{5}$ Se on tehty Sa'diye- eli Djibawiya-veljeskunnan perustajan, 1300-luvun alkupuolella kuolleen damaskoslaisen Sa'd-al-Din Djibawin kunniaksi.

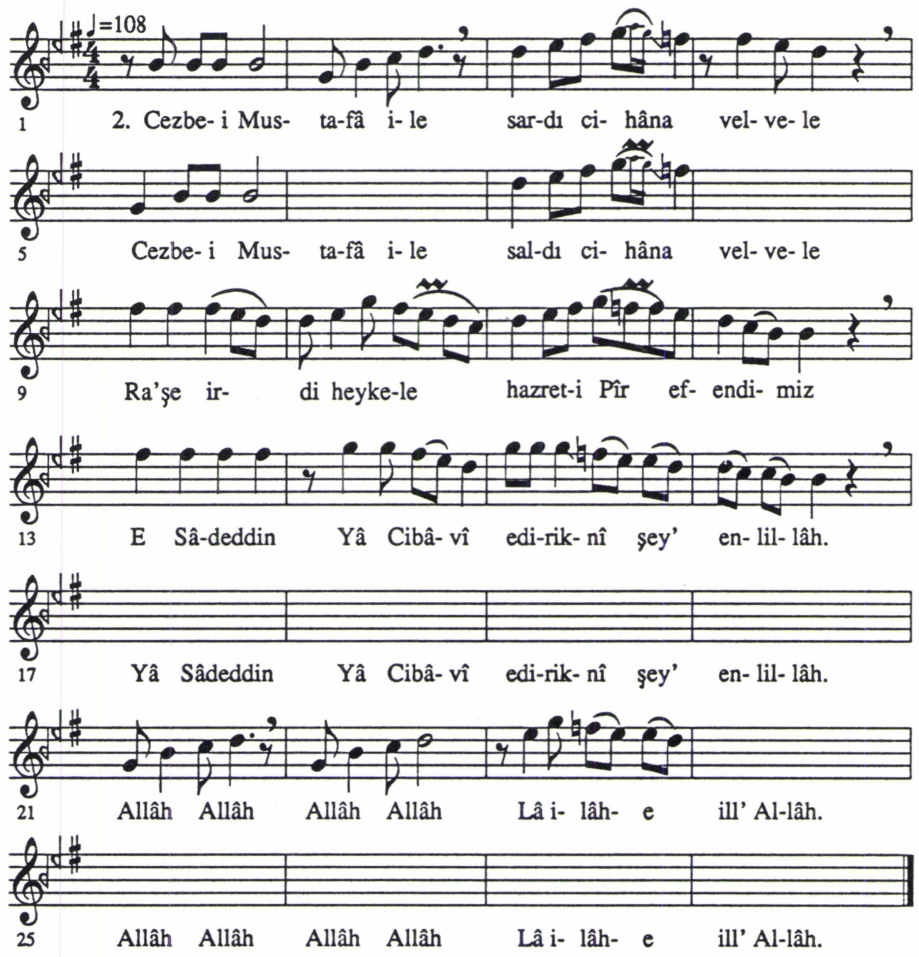

Esimerkki 2. Ilâhi Server-i serbülendimiz. (Turquie: Musique Soufi. Ocora C559017). ${ }^{6}$

5 Şahbeyt ei tue Uzelin käsitystä runoilijan henkilöllisyydestä. Se ilmoittaa kirjoittajaksi Sadi-nimisen henkilön, joka tuskin on sama kuin veljeskunnan perustaja. (Ks. Ergun 1942, 683).

6 Vertailun helpottamiseksi olen nuotintanut toisen säkeistön. 
Nezih Uzelin ja Kudsi Ergunerin levyttämän version kertosäe on painettua versiota pitempi (vrt. Ergun 1942, 683). Tempo on nopea. Laulajia on yksi, ja melodialinjaa koristellaan jonkin verran. Vibraton käyttö sattuu alaspäisiin kulkuihin. Tahdissa 13 Uzel ilmeisesti unohtaa sanat hetkeksi. Säestys koostuu kehysrummusta ja reunahuilusta.

Melodia noudattaa makam segâhia (ks. esim. 1). ${ }^{7}$ Melodialinjan ensimmäinen säe (tahdit 1 ja 2) alkaa toonikasta, josta se nousee dominanttiin. Toinen säe (tahdit 3 ja 4) korostaa dominanttia. Säeparin kertauksen jälkeen kolmas säepari päättyy toonikaan. Tahdista 13 alkavan kertosäkeen säeparien ensipuoliskot päättyvät dominanttiin ja jälkimmäiset toonikaan. Makam on selvästi nouseva. Kolmas, neljäs ja viides säepari alkavat pysähdyksellä fis-säveleen (eviç), minkä vuoksi aiempien säeparien kaareva linja muuttuu ylhäältä toonikaan laskevaksi. Makam segâhille ominainen fis-sävelen tasaantuminen f-säveleksi (acem) tapahtuu jokaisen säeparin jälkiosan alussa.

Kappaleen ensimmäisen säkeistön alussa Uzel laulaa makamin johtosävelen ais (kürdi):

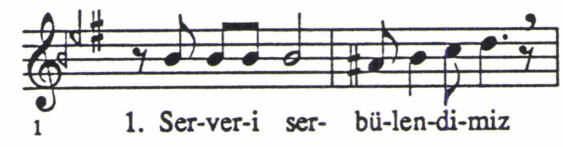

Esimerkki 3. Johtosävel ilâhissa Server-i serbülendimiz. (Turquie: Musique Soufi. Ocora C559017).

Rytmimoodina on usul düyek, jonka eloisa luonne ja useiden tahtien alussa olevat kahdeksasosatauot tuovat esitykseen ilmavuutta ja lennokkuutta. Düyekin perusmuoto on:

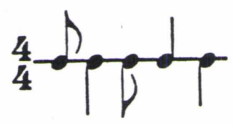

Esimerkki 4. Rytmimoodi düyek. ${ }^{8}$

\footnotetext{
7 Vuonna 1937 kuollut istanbulilainen Ebülhamis Mehdet on säveltänyt saman tekstin segâhia läheisesti muistuttavassa müstear-makamissa. Murat Bardakçı tuntee ainoastaan Mehdetin version.

8 Ylöspäinen nuotinvarsi tarkoittaa matalaa rummuniskua, alaspäinen korkeaa.
} 
Sarajevon versio on äänitetty kaupungin Mevlevi-dervissien zikr-rituaalia seuraavan vapaamuotoisen keskustelun aikana (ks. esim. 5). Sa'd-alDin Djibawin sijasta tämä ilahija kertoo Mevlevi-veljeskunnan perustajasta Mevlâna Celâleddin Rumista. Kappaleen nimikin on vaihtunut Ja Mevlanaksi. Vain ensimmäisen säkeistön ja kertosäkeen teksti on jokseenkin sama kuin Nezih Uzelin versiossa. Şahbeyt ilmoittaa runoilijaksi Ârif-i Rumin. Uzelin (1990) mukaan Sa'diya-ilâhit muuttuivat Mevlevi-ilâheiksi Turkin Konyassa 1970-luvun lopulla. Ja Mevlanan teksti julkaisiin Sarajevon dervissien Šebi-arus -vuosikirjassa jo vuonna 1982, mikä osoittaa kaupungin Mevlevi-veljeskunnan pitäneen kiinteitä yhteyksiä Anatoliaan.

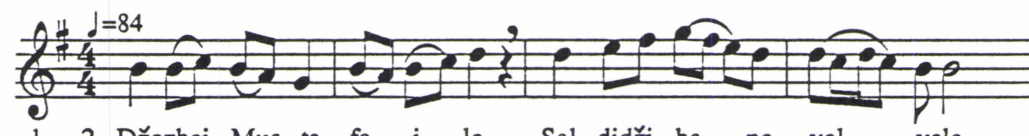

2. Džezbei Mus- ta- fa i- le Sal didži- ha- ne vel- vele.

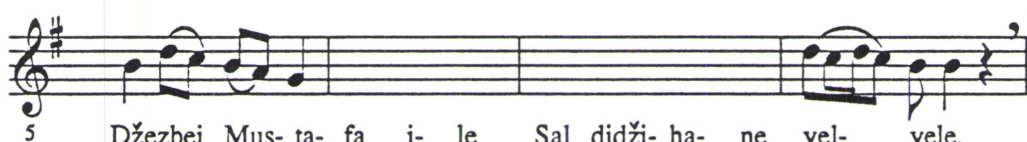

5 Džezbei Mus- ta- fa i- le Sal didži- ha- ne vel- vele.
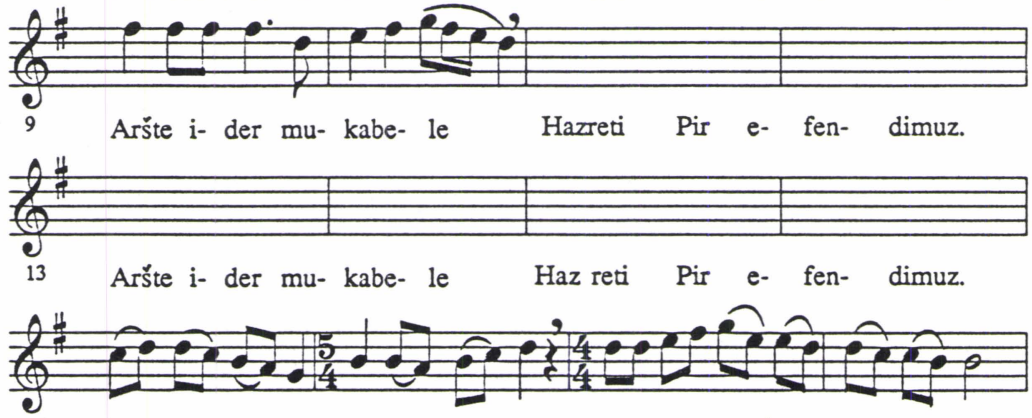

17 Ja Mevla- na, ja Mev la- na, Ede-riki-na šejh- en lil- lah.

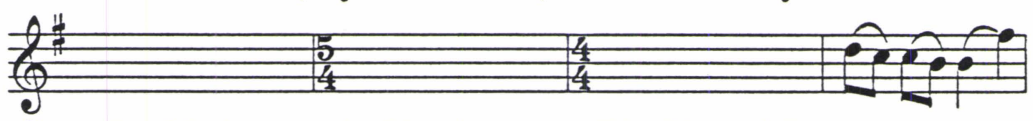

21 Ja Mevla- na, ja Mev la- na, Ede-riki-na šejh- en lil- lah.

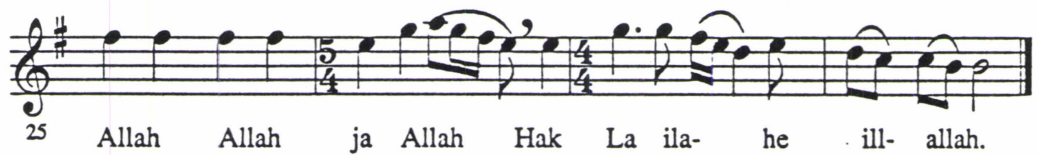

Esimerkki 5. Ilahija Ja Mevlana. (TaY/KPL Y 9745). ${ }^{9}$

${ }^{9}$ Sarajevon dervissit kirjoittavat turkin- ja arabiankielisiä laulutekstejä foneettisesti kroaatin kirjaimiston avulla. 
Tempo on Uzelin versiota hitaampi, ja laulajia on useita. Luultavasti tätä ilahijaa ei esitetä lainkaan solistisesti, sillä se on Sarajevon Mevlevi-jäsenistön ryhmäkoheesiota voimistava laulu, veljeskunnan tunnussävel. Yhteisesityksen ja Bosnian dervissien vähäeleisen laulutyylin vuoksi koristelu on minimaalista. Esitystä leimaa lievä heterofonia. Säestystä ei ole, koska Sarajevon Mevlevi-veljeskunta ei käytä soittimia.

Melodia muistuttaa Uzelin esittämää, mutta siitä puuttuvat kromaattiset muunnokset. Säveljärjestelmät ovat sukua toisilleen: makam segâhin finalista, sisääntuloa, dominanttia ja väliaikaista pysähdystä vastaavat ensimmäinen, kolmas ja viides aste korostuvat Sarajevon versiossa. Kaikki säeparit päättyvät toonikaan. Turkkilainen makam segâh on bosnialaistuessaan yksinkertaistunut fryygisen moodin kaltaiseksi.

Kaksi 5/4-tahtia muuten tasajakoisessa ympäristössä tuo sävelmään yllätyksellisyyttä. Turkkilaisesta näkökulmasta nämä 5/4-tahdit ovat häiritseviä poikkeamia käytetystä rytmimoodista, ja ne saattavat johtua hengitystauoista paljon ilmaa vaativien vokaalien jälkeen. ${ }^{10}$ Tahdin ensimmäisen iskun korostaminen tekee Sarajevon versiosta rytmisesti kulmikkaan. Turkkilaisen teorian kannalta vallitsevana rytmimoodina ei ole düyek, vaan sofiyân (ks. esim. 6).

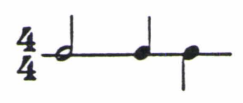

Esimerkki 6. Rytmimoodi sofiyân.

\section{Melodian säerakenteen vertailu}

Server-i serbülendimiz -ilâhin ja Sarajevon dervissien Ja Mevlana -ilahijan melodisen säerakenteen voi tulkita seuraavasti:

\begin{tabular}{ll|}
$\mathrm{a}$ & $\mathrm{b}$ \\
$\mathrm{a}$ & $\mathrm{b}$ \\
$\mathrm{c}$ & $\mathrm{b}^{\prime}$ \\
$\mathrm{c}^{\prime}$ & $\mathrm{b}^{\prime \prime}$ \\
$\mathrm{c}^{\prime}$ & $\mathrm{b}^{\prime \prime}$ \\
$\mathrm{a}^{\prime}$ & $\mathrm{b}^{\prime \prime \prime}$ \\
$\mathrm{a}^{\prime}$ & $\mathrm{b}^{\prime \prime \prime}$ \\
\hline
\end{tabular}

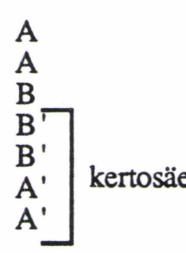

\begin{tabular}{|ll|}
\hline $\mathrm{a}$ & $\mathrm{b}$ \\
$\mathrm{a}$ & $\mathrm{b}$ \\
$\mathrm{c}$ & $\mathrm{b}$ \\
$\mathrm{c}$ & $\mathrm{b}$ \\
$\mathrm{a}^{\prime}$ & $\mathrm{b}$ \\
$\mathrm{a}^{\prime}$ & $\mathrm{b}$ \\
$\mathrm{c}^{\prime}$ & $\mathrm{b}$ \\
\hline
\end{tabular}

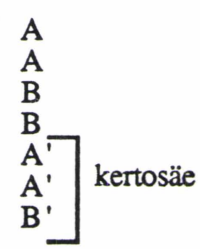

Taulukko 1. Nezih Uzelin Server-i serbülendimiz -ilâhin ja Sarajevon dervissien Ja Mevlana -ilahijan melodinen säerakenne.

10 Tästä selityksestä olen kiitollinen professori Timo Leisiölle. 
Uzelin esityksen säeparien jälkiosien muuntelu on silmiinpistävän runsasta. Varsinainen tekstiltään muuttuva osa sisältää kertautuvan säeparin A ja kertautumattoman säeparin B. Läpi koko ilâhin samana pysyvä kertosäe koostuu kahdesta kertautuvista säepareista B' ja A'. Kertosäe siis hyödyntää jo aiemmin käytettyä materiaalia. Kappaleen rakenteen voi tiivistää muotoon $\mathrm{ABA}$. Tämä poikkeaa ilâhien yleisimmistä säerakenteista, jotka ovat Özkanin $(1984,83)$ mukaan AB ja ABCB.

Sarajevon dervissien versiossa kaikkien säeparien jälkiosat pysyvät lähes muuttumattomina. Tekstiltään muuttuva osa sisältää kertautuvat säeparit $\mathrm{A}$ ja $\mathrm{B}$. Myös tämän version kertosäe perustuu aiemmin esiintyneeseen materiaaliin. Kertaamiseen perustuvan rakenteen kannalta on hieman yllättävää, ettei kertosäkeen päättävä säepari $\mathrm{B}^{\prime}$ toistukaan. Kappaleen muotorakenne on pelkistettynä ABAB.

\section{Erään ilahijan alkuperä}

Petrović $(1989,140)$ on nuotintanut sarajevolaisen Hamdija Šahinpašićin esittämän tunnetun ilahijan Džundi Lutvik (ks. esim. 7). Hän ilmoittaa erheellisesti tekstin olevan turkkia. Tosiasiassa se on kuitenkin lähes tunnistamattomaksi muuttunutta arabiaa.

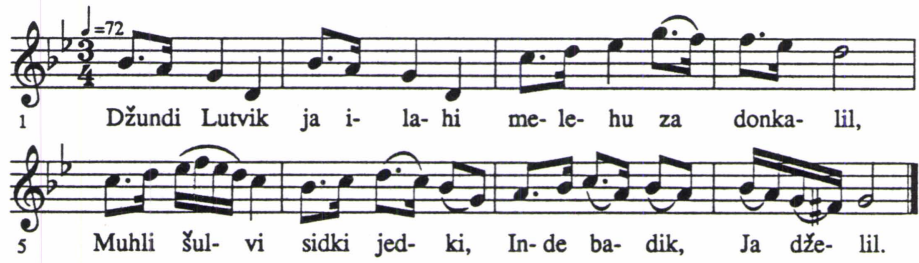

Esimerkki 7. Ilahija Džundi Lutvik. (Petrović 1988, 140).

Kuten Petrović huomauttaa, kaupunkiperinteeseen kuuluvassa suositussa sevdalinka-rakkauslaulussa laulussa Kad ja podjoh na Bembašu on sama melodia:

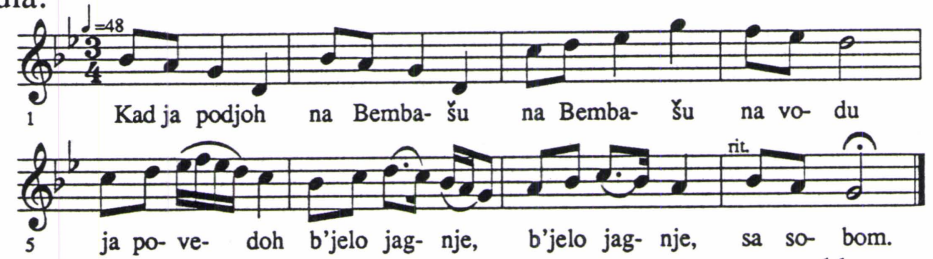

Esimerkki 8. Sevdalinka Kad ja podjoh na Bembašu. (Cenerić 1973, 18). ${ }^{11}$

11 Diplomikitaristi Samuli Juvonen kertoo oppineensa saman melodian Kannuksen yhteiskoulun ensimmäisellä luokalla vuonna 1964. Laulun suomenkielinen nimi on Muistoja 
Sarajevolainen dervissi Seid Strik $(1987,152)$ väittää omassa kirjoituksessaan samaa kuin Petrović: Džundi Lutvik on alkuperältään turkkilainen. Strikin mielestä ilahijan melodia on siirtynyt Kad ja podjoh na Bembašu -lauluun, ja hän on havainnut monia muitakin vastaavia lainaumia. Hän katsoo vaikutteiden aina siirtyneet ilahijoista sevdalinkoihin, sakraalista profaaniin.

Džundi Lutvik -sävelmä on poikkeuksellinen sekä ilahijana että sevdalinkana. Sen itämaista alkuperää on syytä epäillä; sävelmä on selvästi tonaalinen. Asteikko muistuttaa turkkilaista makam nihâvendia, mutta melodialinja ei käyttäydy sen mukaisesti. Lisäksi 3/4-tahtilaji on harvinainen turkkilaisessa taidemusiikissa. Sitä on käytetty etenkin 1800-luvulla jäljiteltäessä länsimaista tyyliä (ks. Reinhard 1973, 23).

Itse asiassa sävelmä on kuin amerikkalaisen Percy Montrosen 1884 julkaiseman Clementine-laulun masurkkamainen mollimuunnos. Sevdalinka-version ja Clementine-sävelmän vertailu tuo esille lukuisia rinnakkaisia priimi-, terssi- ja kvarttikulkuja (ks. esim. 9). Muutenkin melodialinjat kulkevat samansuuntaisesti. Sävelmillä saattaa hyvinkin olla yhteinen keskieurooppalainen esikuva.

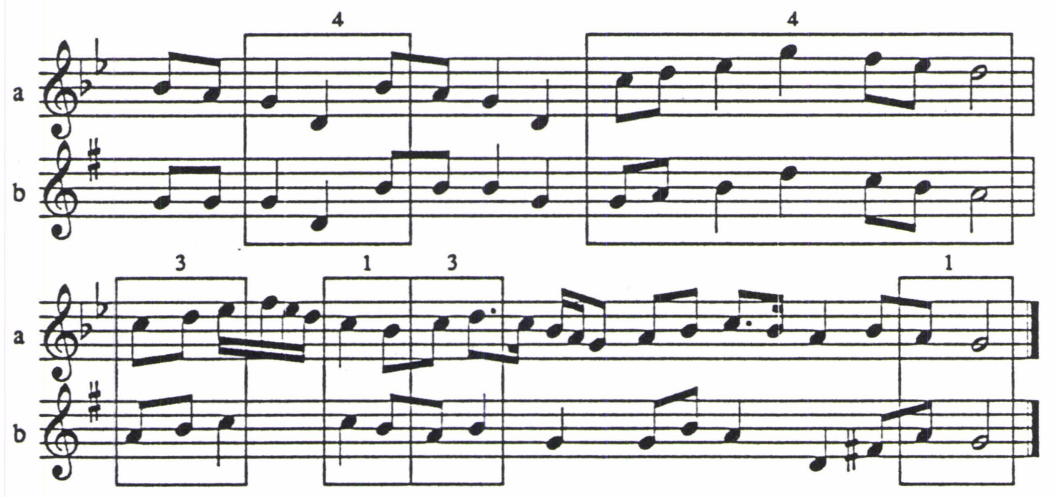

Esimerkki 9. Kad ja podjoh na Bembašu (a)- ja Clementine (b)-sävelmien rinnakkaiskulut.

\section{Tekstin turkkilainen sävelasu}

Džundi Lutvik eli oikeammin Cüd bilutfek ya ilâhi on tuntemattoman turkkilaisen runoilijan kirjoittamaa kieliopillisesti oikeaa, muttei kielen konventioiden mukaista arabiaa. Metriikka on persialais-turkkilaista.

Benbašista, ja se opetettiin bulgarialaisena kansanlauluna. 
(Bardakçı 1991).

Turkissa arabiankielisiä ilâheita kutsutaan nimellä şuğul. Ne ovat nopeita melodioita, joita dervissit esittävät transsia tavoittelevan zikr-rituaalinsa esmayi celâl -osan jälkeen. Bardakçın (ibid.) mukaan tämä ilâhi-laji syntyi 1800-luvun loppupuoliskolla turkkilaisten säveltäjien paettua sulttaani Abdülhamid II:n (1876-1909) konservatiivista hallintoa Kairoon. Abdülhamidin noudattama pan-islamismi antaa kuitenkin uskottavamman selityksen arabiankielisten ilâhi-tekstien synnylle. Arabian käyttöä osmanien valtakunnan kulttuurielämässä ja jopa hallinnossa rohkaistiin ideologisista syistä (ks. Shaw 1977, 259-260).12

Tuntemattoman turkkilaissäveltäjän laatima Cü bilutfek ya ilâhi -şuğulin versio poikkeaa bosnialaisesta vastineestaan sekä makamiltaan että rytmimoodiltaan, joka on düyek:

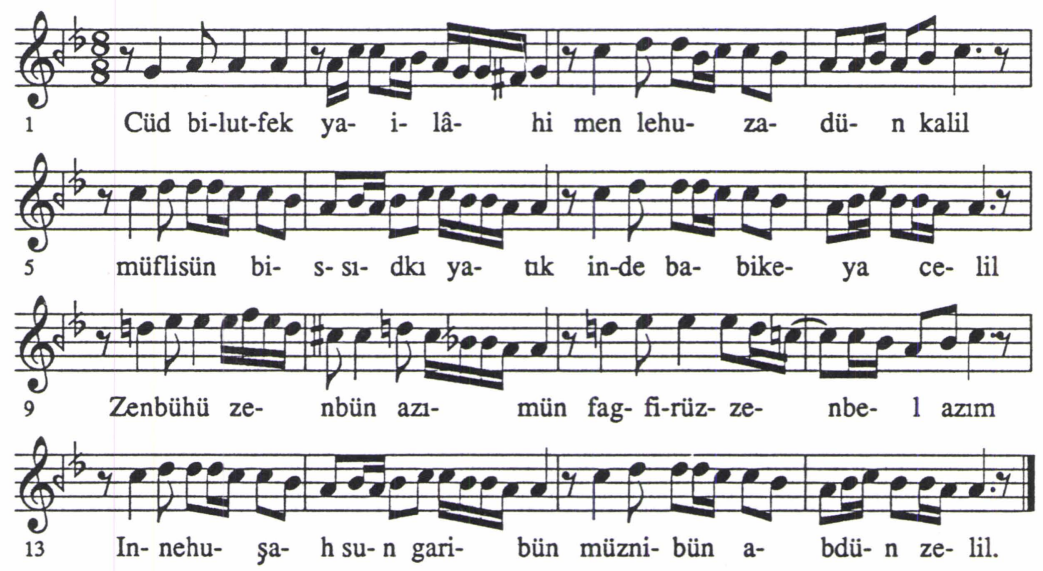

Esimerkki 10. Şuğul Cüd bilutfek ya ilâhi. (Yekta et al. 1933, 144).

Sävellyksen rakenne on turkkilaiselle taidemusiikille hyvin tyypillinen. Sävelmän kaksi ensimmäistä säeparia ovat makam sabâssa, kolmas moduloi tahtien 9, 10 ja 11 ajaksi makam hicaziin (ks. esim. 11). Tahdin 11 loppu ja tahti 12 valmistelevat paluuta makam sabâan, ja tahti 12 päättyy kadenssiin makam sabân dominanttiin eli c-säveleen (çargâh). Sävellyksen neljäs säepari on tavan mukaan sama kuin toinen säepari. Säerakenne noudattaa kaavaa $\mathrm{ABCB}$. Modaalinen muotorakenne on

12 Cüd bilutfek ya ilâhi -teksti on saattanut saapua Bosniaan suoraan Anatoliasta jo Abdülhamid II:n kaudella, sillä sulttaani käytti oikeuttaan valita uskonnolliset viranomaiset vieraiden valtioiden hallintaan joutuneille entisille osmanien alueille, myös Bosnia-Hertsegovinaan (ks. Shaw 1977, 260). 
turkkilaisessa taidemusiikissa erittäin yleinen ABA. ${ }^{13}$
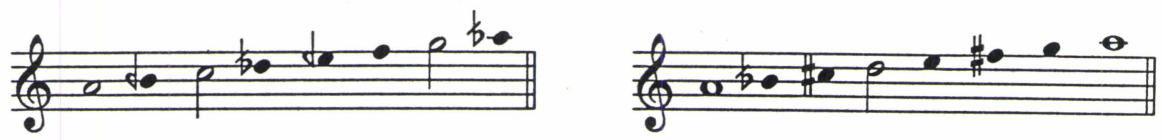

Esimerkki 11. Makam sabâ ja makam hicaz.

Turkkilaisen klassisen sävellyksen esittelyjakso eli A-osa on nimeltään zemin. Vaikka zeminissä olisikin väliaikaisia modulaatioita, sen tehtävä on vakiinnuttaa sävellyksen perus-makam. B-jaksoa kutsutaan nimellä meyan eli miyan. Se sisältää siirtymän perus-makamin ylärekisteriin tai modulaation toiseen makamiin.

Cüd bilutfek -runon loppusoinnullisuus rikkoontuu kolmannessa säkeessä eli sävellyksen meyan-osassa:

... kalil

... celil

... azım

... zelil

Teksti ja sävelmä on sidottu lujasti yhteen, sillä makamin vaihtuminen korostaa runon rakennetta. Sarajevolaisessa versiossa runon nelisäkeinen gazel-muoto on hajotettu kahden säkeistön alalle. Tämä kielii siitä, että Džundi Lutvik -ilahijan teksti ja melodia ovat löytäneet toisensa vasta Bosniassa.

\section{Itävalta-Unkarin kausi ja Bosnian kaupunkimusiikki}

Urbaaneille sevdalinka-rakkauslauluille on ominaista laaja ulottuvuus, melismaattisuus, kromatiikka, metrinen vapaus, melodiasäkeiden pitkälinjaisuus ja ylinouseva sekunti-intervalli. Tavallisimmat skaalat ovat harmoninen molli sekä miksolyydinen ja duuriasteikko. Finalis on usein toinen aste. (Milošević 1964, 33-34).

Milošević $(1957,109)$ on päätynyt informanttiensa avulla ajoittamaan Kad ja podjoh -runon syntyajankohdan 1850-luvulle. Safet Isovićilta tallennettu Kad ja podjoh -sävelmä saattaa olla peräisin noilta ajoilta (ks. esim. 12). ${ }^{14}$ Siinä kertomuksen etenemistä hidastetaan

13 Musiikkianalyysi pohjautuu Signellin (1977, 82-83) kuvaukseen.

14 Laulun muita bosnialaistyylisiä toisintoja ks. Milošević 1957, 109 ja Bartók 1978, 224. 
tekstin runsaan kertaamisen ja turkkilaisesta musiikista omaksuttujen aman- ja džanum-interjektioiden avulla. ${ }^{15}$ Kaksi- ja kolmijakoisten tahtien jatkuva vaihtelu eli potkorak on tyypillistä bosnialaiselle ja yleensäkin jugoslavialaiselle maaseutu- ja kaupunkimusiikille. Se poikkeaa turkkilaisvaikutteisesta ns. aksak-rytmiikasta. (Ks. Rihtman 1980, 589). Isovićin miksolyydinen versio päättyy toiselle asteelle.

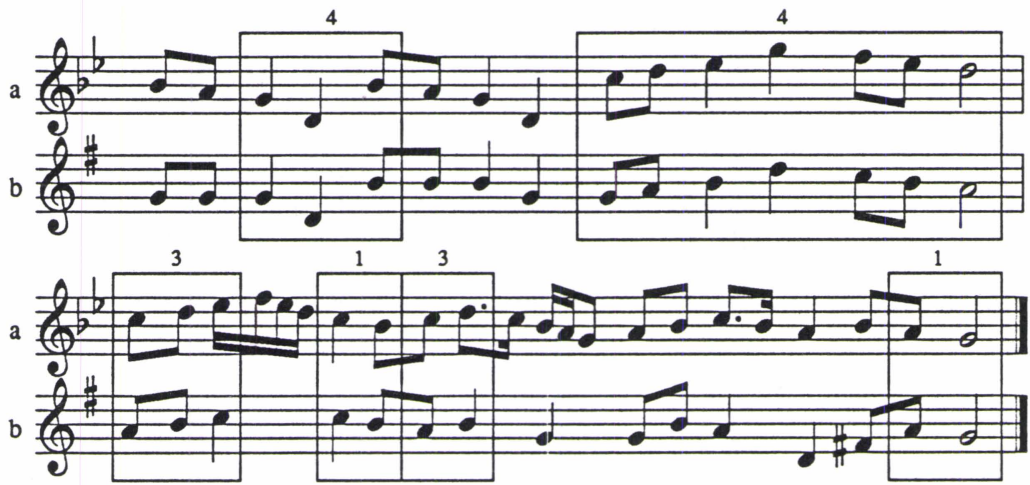

Esimerkki 12. Safet Isovićilta tallennettu sevdalinka Kad ja podjoh na Bembašu. (Cenerić 1973, 19).

On ilmeistä, että jossain historian vaiheessa bosnialaisen tyylin mukaiset Kad ja podjoh -sävelmät saivat rinnalleen uuden kolmijakoisen melodian, jossa teksti etenee ilman kertauksia ja interjektioita. Uudempi sävelmä saattaa hyvinkin olla peräisin Keski-Euroopasta. On tietysti mahdollista, että sävelmä syntyi Bosniassa, mutta sen esikuvat ovat selvästi keskieurooppalaisia. Joka tapauksessa kolmijakoisen Kad ja podjoh -sävelmän siirtyminen sevdalinkasta ilahijaan tuntuu todennäköisemmältä kuin päinvastainen akkulturaatiosuunta.

Itävalta-Unkari valtasi Bosnia-Hertsegovinan osmaneilta vuonna 1878. Uusien vallanpitäjien perustamaa koululaitosta voi pitää luontevana musiikillisten vaikutteiden kulkeutumiskanavana. Eurooppalaistyylistä opetusta alettiin antaa vuoden 1880 tienoilla, joskin bosnialaiset - etenkin muslimit ja serbit - vastustivat aluksi valtion kouluja. Yleinen oppivelvollisuus astui voimaan vuonna 1912, mistä lähtien ainakin osa maakunnan muslimilapsista alkoi saada länsimaista koulutusta. (Papić 1983, 208-209).

Kolmijakoinen Kad ja podjoh oli aikansa hitti. Tästä kertoo se, että sävelmää on käytetty myös kahdessa Sarajevon sefardijuutalaisten sapat-

15 Aman 'Ah!', 'Voi, voi!'; Džanum 'Oi, sieluni!'. 
tilaulussa. Petrovićin mukaan osmanien valtakauden aikana sosiaalisesti, kielellisesti ja uskonnollisesti eristäytyneiden Bosnian juutalaisten sakraali musiikki alkoi saada ulkopuolisia vaikutteita vasta maakunnan muututtua Itävalta-Unkarin osaksi. (Petrović 1982, 36; 45; ibid. 1989, 141). Kad ja podjoh -sävelmän juutalaisversio ajoittuu siis aikaisintaan 1880-luvulle.

Islamilainen kulttuuri heikentyi Bosnia-Hertsegovinan muututtua viime vuosisadan viime neljänneksellä osmanien valtakunnan provinssista ensin Itävalta-Unkarin ja ensimmäisen maailmansodan jälkeen Serbien, kroaattien ja sloveenien kuningaskunnan osaksi. Musiikissa tämä näkyy siten, että länsimaiset sekulaarit vaikutteet pystyivät tunkeutumaan jopa islamilaiseen sakraaliin laulantaan.

On kuitenkin kiintoisaa - ja äärin vierin inhimillistä - että BosniaHertsegovinan muslimien musiikkia on tarkasteltu turkkilais-bosnialaisten silmälasien läpi. Nationalismin alettua vaikuttaa 1800-luvulta lähtien etnisesti hajanaisella Balkanilla jokainen kansallisuus on halunnut erottautua muista. Bosnian muslimien musiikillisen identifikaation välineiksi ovat kelvanneet esimerkiksi kauaksi alkuperäisestä erkaantunut modaalinen järjestelmä ja turkkilaiseksi luultu hymni, jonka sävelmä onkin lähinnä keskieurooppalainen.

Bosnian muslimien musiikkikulttuuri on hyvä esimerkki kahden voimakkaan kulttuurikeskuksen välimaastossa sijaitsevasta marginaalikulttuurista. Maakunnan muslimit ovat yhdistäneet Bosnian maaseudun musiikin Lähi-idästä ja Keski-Euroopasta vastaanottamiinsa innovaatioihin. Lopputulos on omaperäinen kokonaisuus, joka on enemmän kuin osiensa summa. Tarvitaan vielä runsaasti tutkimustyötä ennen kuin bosnialaisen musiikin luonne ja sen kokemat akkulturaatioprosessit kyetään selvittämään ja asettamaan historiallisiin yhteyksiinsä. 


\section{Kirjalliset lähteet}

Bartók, Béla

1978 Yugoslav Folk Music. Volume One. toim. Benjamin Suchoff. New York.

Boratav, P.N.

1971 Ilâhî. Encyclopedia of Islam. Volume III. New Edition: 1094. toim. B. Lewis et al. Leiden - London.

Cenerić, Ivo (toim.)

1973 Narodne pjesme iz Bosne i Hercegovine 1. Sarajevo.

Dietrich, Wolf

1983 Orient/Okzident: Musik aus Südost-Europa. Museum Collection Berlin (West) MC 3.

Ergun, Sadettin Nizhet

1942 Türk musikisi antolojisi. Istanbul.

Filipović, Muhamed \& Hadžidedić, Nedžad

1983 Nations and Nationalities of Bosnia and Hercegovina. The

Socialist Republic of Bosnia and Hercegovina.

Enciklopedija Jugoslavije: 120-127. Zagreb.

Hadžisalihović, Jasna

1973 Bosanski mekam. 18. Zbornik kongresa jugoslovanskih folkloristov; Bovec 1971: 248-250. toim. Zmaga Kumar. Ljubljana.

Kuhać, F.

1898 Turski živalj u pučkoj glazbi Hrvata, Srba i Bulgara. Glasnik Zemaljskog muzeja x: 175-217. Sarajevo.

Lockwood, William G.

1975 European Moslems. Economy and Ethnicity in Western

Bosnia. Studies in Anthropology. New York - San

Francisco - London.

Milošević, Vlado

1957 Bosanske narodne pjesme. Knjiga 2. Banja Luka.

1964 Bosanske narodne pjesme. Knjiga 4. Banja Luka.

1983 Melografija arapskih tekstova »Suretum-Nahl» i »Salla». Papić, Mitar Radovi. Knjiga LXXIII: 57-70. Sarajevo.

1983 Elementary Education. The Socialist Republic of Bosnia and Hercegovina. Encilopedija Jugoslavije: 207-210.

Zagreb. 
Pennanen, Risto Pekka

1990 Sarajevon dervissien sakraali laulanta. Etnomusikologian vuosikirja 1989-90: 150-175. toim. Vesa Kurkela et al. Jyväskylä.

Petrović, Ankica

1982 Sacred Sephardi Chants in Bosnia. The World of Music 3/1982: 35-48.

1989 Paradoxes of Muslim Music in Boznia [sic] and Herzegovina [sic]. Asian Music. Fall/Winter 1988/89: 128147.

Reinhard, Kurt

1973 Die Türkei im 19. Jahrhundert. Musikkulturen Asiens, Afrikas und Ozeaniens im 19. Jahrhundert. Studien zur Musikgeschichte des 19. Jahrhundert. Band 31: 21-42. toim. Robert Günther. Regensburg.

Rihtman, Cvjetko

1967 Orientalische Elemente in der traditionellen Musik Bosniens und der Herzegowina. Grazer und Münchener Balkanologische Studien. Beiträge zur Kenntnis

Südosteuropas und des Nahen Orients II, xxx. 97-105. toim. H.-G. Beck et al. München.

1980 Bosnia and Hercegovina.The New Grove Dictionary of Music and Musicians. Volume 20: 588-594. London.

Schimmel, Annemarie

1982 As Through a Veil. Mystical Poetry in Islam. New York. Shaw, Stanford J.

1977 History of the Ottoman Empire and Modern Turkey. Volume II. Cambridge - London - New York Melbourne.

Signell, Karl L.

1977 Makam. Modal Practice in Turkish Art Music. Asian Music Publications. Series D, Number 4. Washington. Spaić, Jasna

1989 Islamsko obredno pjevanje po bosanskom mekamu. Akademija nauka i umjetnosti Bosne i Hercegovine. Nauče komunikacije XXIII. Prvi javni sastanak.

Međuakademisjskog koordinacionog odbora za ispitivanje tradicionalne narodne religiozne obredne muzike $u$ Jugoslaviji: 43-52. Sarajevo.

Strik, Seid 
1987 Ilahije. Šebi-arus 87. Sarajevo.

Yekta, Rauf et al. (toim.)

1933 Ilâhiler II. Istanbul konservatuarı neşriyati. Istanbul. Özkan, Ismail Hakkı

1984 Türk mûsikîsi nazariyatı ve usûlleri. Kudüm velveleri. Istanbul.

\section{Tallenteet}

Bardakçı, Murat

1991 Istanbul 19.6.1991. Haastattelijana Risto Pekka Pennanen.

Turquie: Musique Soufi. Ocora C559017. 1987.

Uzel, Nezih

1990 Helsinki 12.6.1990. Haastattelijana Risto Pekka Pennanen.

TaY/KPL Y 9745 Mevlevi-zikr Sarajevossa 19.2.1988. Tampereen yliopiston Kansanperinteen laitos. Äänittänyt Risto Pekka Pennanen. 